\title{
CSR Infrastructure for Communication and the Nike Controversy
}

\author{
Paul Ziek ${ }^{1}$ \\ ${ }^{1}$ Department of Media, Communications and Visual Arts, Pace University, Pleasantville, New York, United \\ States \\ Correspondence: Paul Ziek, Department of Media, Communications and Visual Arts, Pace University, \\ Pleasantville, New York, United States. Tel: 1-914-773-3672. E-mail: pziek@pace.edu
}

Received: July 25, 2012 Accepted: August 21, 2012 Online Published: October 9, 2012

doi:10.5539/jms.v3n1p63 URL: http://dx.doi.org/10.5539/jms.v3n1p63

\begin{abstract}
Where most literature explains Corporate Social Responsibility (CSR) communication through Resource Dependency and Institutional Theories, this study investigates how the emergence and maintenance of an infrastructure for communication influences organizational communicative behavior. The infrastructure for communication is a repertoire of materials that act as a tacit framework for the preferred forms of communicative strategy and instrumentation among a community of organizations. This is a longitudinal study of the controversy surrounding Nike's supply chain from 1993 to 2004. To draw conclusions about the nature of an infrastructure requires a form of analysis known as infrastructural inversion, which is a reflective practice that involves assessing the communication and interaction of actors to ascertain the relevant patterns that impact behavior. The main finding of the study is that infrastructure shaped how the organizations behaved by acting as a coordinating device for the symbolic and material qualities of inter-organizational communicative strategy and instrumentation.
\end{abstract}

Keywords: CSR, communication strategy, communication instrumentation, infrastructure

\section{Introduction}

\subsection{Introduction to the Problem}

Corporations are not isolated bureaucracies but erected out of and shaped by interactions with internal and external stakeholders. One of the most challenging forms of stakeholder interaction is how to mediate the assumption that business has increased social and environmental responsibility. Along with becoming more socially responsible through programs and initiatives, business has developed a plethora of CSR communicative strategies and instruments. Strategies such as aligning with other organizations, creating persuasive (i.e., compliance, sanctioned, appeal, command) or argumentative (i.e., opposition, reasoned, motivated) message campaigns and instruments such as Web sites, speeches, advertisements, stakeholder meetings and company letters. Following this practical trend, numerous academic studies have attempted to explain what is happening as organizations engage in the strategic and instrumental aspects of CSR communication.

Most of the literatureis developed from a Resource Dependency or Institutional perspective which effectively ties strategy and instrumentation to organizational environment. However what is overlooked in the literature is that communication is constitutive of behavior. Although research done under both of these conceptual umbrellas has certainly extended the understanding of how and why organizations make certain communicative choices, they do not sufficiently attend to the potential influence of routines and patterns of communication. In other words, the process of inter-organizational communication is generative of the roles that both corporations and stakeholders play and the way they send, receive, interpret and act on each other's strategy and instrumentation.

To illustrate how communication is constitutive of organizational behavior, the current study investigates how the emergence and maintenance of an infrastructure for communication influences organizational communicative behavior.An infrastructure for communication is a repertoire of materials that surfaces to constrain and afford the communicative behavior of actors. It is a system of meaning making and management that is best seen during 
controversy because it works conjunction with the political, cultural and economic order to frame who talks, when and how.

\subsection{Why Organizations Communicate CSR}

There are two rationales in the CSR literature that are widely used to explain the conditions under which business is likely to act in socially and environmentally responsible ways. The first rationale is best illustrated by Kotler and Lee's (2005) explanation that organizations act in responsible ways because they have recognized the opportunities for bottom-line benefits. This rationale underlies the idea that the strategic practices of CSR must provide tangible economic value to the firm (see also Porter \& Kramer, 2005). The second rationale is best illustrated by Campbell's (2001) explanation that organizations act in responsible ways when the social context supports and enforces CSR. This rationale underlies the idea that the strategic practices of CSR must provide the organization legitimacy in its social-political context.

The two rationales for how CSR becomes part of business practice maps to two general theories of organizational behavior. The first, that CSR is a way to gain access to the necessary resources (i.e., Kotler \& Lee, 2005), corresponds to Resource Dependency Theory and the second, that CSR happens due to anticipation of, or response to, contextual pressures (i.e., Campbell, 2001) corresponds to Institutional Theory. Resource Dependence Theory argues that organizations look to establish relationships with other organizations in order to gain access to needed resources (Pfeffer \& Salancik, 1978). This approach to inter-organizational behavior explains that inter-organizational relationships are formed because organizations seek, in an instrumentally rational manner, the best opportunity for resource exchanges. Institutional Theory points out that organizational action, including instrumentally-rational action, is subject to routines, rituals, and the symbolic context in which the organizations act (DiMaggio \& Powell, 1991; Scott, 2004). Inter-organizational relationships are formed due to normative, mimetic, or coercive causes that may even be independent of instrumentally rationale resource exchange.

In both cases, Resource Dependency and Institutional Theories highlight a role for communicative strategy and instrumentation. Indeed there has been a great deal of research that explains CSR communicative strategy and instrumentation from a Resource Dependency and Institutional Theory perspective. Branco and Rodrigues (2006), Jawahar and McLaughlin (2001), Jones and Bartlett (2009) and Nielsen and Thomsen (2011) describe communication as a tool that gives an organization access to the necessary resources required to develop socially responsible programs and initiatives. And Campbell (2006), Lammers (2003) and Schultz and Wehmeier (2010) explain how communication enables organizations to manage a socially responsible identity in the ritual based symbolic fields that they operate. Both approaches though overlook what happens when business and society debate social and environmental issues during resource exchange or cultural acceptability. They do not sufficiently attend to the potential influence misunderstanding, disagreement, and opposition has on the choice of communicative strategy and instrumentation. Therefore thecurrent study looks to explain what happens during CSR controversy. More particularly, the way that organizations deal with the consequences of interaction during controversy matters in the trajectory of inter-organizational communication.

\subsection{CSR Controversy and Communication}

There are many reasons that contribute to a firm's decision to increase its social responsibility including: the positive impact CSR has on consumer behavior (Alniacik, Alniacik, \& Genc, 2011); how CSR programs and initiatives enable organizations to attract and retain employees (Turban \& Greening, 1997); and, how investors and investment indexes have a rising concern about CSR (Collison, Cobb, Power \& Stevenson, 2008). It is also the case that certain corporations are forced into acting more responsibly when their behavior is called-out during controversy (Aakhus \& Ziek, 2008).

A controversy is a state of prolonged public disagreement concerning matters of opinion. Due to the fact that interaction can spiral in multiple directions, a controversy is a tenuous endeavor. It is an event that involves a corporation engaging stakeholders by inventing and reinventing communicative strategy and instrumentation as well as how stakeholders invent and reinvent strategy and instrumentation that engage and otherwise influences the corporation.Yet at the same time, solutions do emerge. As actors frame their arguments they enter into mutually understood forms that indicate a set of commitments to preferred communication (e.g., Goffman, 1981; Levinson, 1979). In other words, as stakeholders make claims on corporations, and corporations respond to these claims, preferred forms of communication emergethat organizesactors into patterns of who talks, when and how.

These preferred forms of communication are an infrastructure for communication. Infrastructure for communication is astandardization of roles, moves and instruments that enable organizations to navigate controversy (Aakhus \& Ziek, 2009; Ziek, 2012). It is a design for communication that structures interaction so 
that exigencies are controlled through rules and procedures. As organizations work to controlinteraction during a controversy, an infrastructure for communication emerges that pushes the organizations toward particular communicative effects and away from others. Therefore, as the infrastructure arises to help organizations overcome the inherent problems associated with addressing multiple competing demands for interaction, it prompts what is possible in terms of CSR communicative strategy and instrumentation.

\subsection{Infrastructure for Communication}

Infrastructure for communication has received considerable attention particularly as it is associated with the nuances related to technological networks and advanced information systems (see Ciborra, 2000; Graham, 2000). Studies show a network or system's ability to perform actions and to permit, promote and facilitate the orderly, standardized and heterogeneous behaviors among users (Cronholm, Ågerfalk \& Goldkuhl, 1999). Yet recently the notion of infrastructure has been widened to encompass the intersection between symbolic, technical and social mechanisms so that patterns of standards that reach beyond a single event (Star \& Ruhleder, 1996) can be explained in a broad, relational sense.

Following in the relational line of thinking, Bra, Hanseth, Woinshet, Heywood and Shaw (2007) explain that infrastructure is determined by the constituting actor network (users, implementers, designers) and the links of various kinds between all of these actors. Frederico (2010) adds that infrastructure is a domain of activity that stems from the weight of how language creates and sustains authoritative guidelines for social behavior. To that end, infrastructure is a relational concept that grows out of the communication and interaction that connects actors (Hanseth \& Monteiro, 1996). It is the framework of rules, procedures and arrangements that set out the prescriptions about situational behaviors. In this sense then, as organizations attempt to shape a web of interactions relative to environmental and social issues what gets built-up are preferred forms of communication that offer solutions to the ongoing demand for interaction.

Unlike structure in a classical sense that emphasizes how ties emerge from routine, infrastructure accentuates how routine evolves from communicative ties that connect organizations. Structuration posits that structure is an instantiation and co-orientation of memory traces and is marked by an absence of the subject (Giddens, 1984). In other words, in structuration, structure is the framework of rules and resources that are internal to agents (Banks \& Riley, 1993) and therefore "social structures are brought into interaction, they are instantiated in social life" (DeSanctis \& Poole, 1994, p. 125). Infrastructure stands in contrast to standard views of structuration because it emerges from the communicative actions (i.e., strategies and instruments) actors perform to shape interaction. Infrastructure for communication is an artifact with physical and pragmatic properties (Star, 1999) in that it is generated from the effort to manage the demands for interaction within a controversy.

Infrastructure is not one thing to be identified; it is a framework of multiple patterns such as actor roles, content rules, instrumental procedures, etc. Infrastructure signifies all the institutionalized resources and practices that actors require to carry out their interactions (e.g., Kling, 1987; Kling \& Scacchi, 1982). This includes things like rules for turn-taking; how text depicts the world, values and assumptions; the language of the text i.e. scientific, affective, jargon, etc.; the definition of words and acronyms; templates, timing and appearance of channels and instruments; how issues are introduced into a relationship; the social function of action that an organization is committing to; and even the tone of depictions which constitutes the level of permissible of reflections of emotional states. Just like on an interpersonal level, patterns, routines and rituals evolve from the repeated practices of interconnected and interdependent organizations. Infrastructure then is an organization of communication that is not ready made but shaped through the social processes of the organizations - it is a system that is generated by communication and subsequently enables and constrains how that communication is forged, maintained and plays-out.

For example, in the 1990s, Chiquita Banana was involved in a controversy stemming from questions related to gender-based pay-inequality and forcibly preventing its plantation workers to unionize (Radin \& Culkins, 2006). What emerged from the back-and-forth move-countermoves between Chiquita Banana and its stakeholder was a blueprint for how the corporation would deal with future demands for interaction. The acceptable communicative behavior was the development of annual CSR reports that conveyed Chiquita's commitment to increased social responsibility. And after being questioned by numerous stakeholder groups about not buying Fair Trade coffee, Starbucks developed and still maintains a strategy of collaboration with NGOs to promote the coffee-growing practices of small farms (Argenti, 2004; Austin \& Reavis, 2002). In both cases, an infrastructure for communication (i.e., rules, norms and procedures) emerged to push the organizations to respond to the controversy in particular ways and through particular means. However this is only anecdotal evidence of 
infrastructure at work. The notion that a system of communication management arises to give order to the way corporations deal with claims is only implied in studies of CSR controversy.

To this point, there has been no empirical investigation modeling infrastructure at the inter-organizational level. Indeed Star (1999) explains that "we need new methods to understand the imbrications of infrastructure and human organization" (p. 379). Accordingly, the current study is expletory - the purpose is to model a CSR controversy over time to see how infrastructure for communication happens and its consequences on how particular communicative possibilities are given shape in stakeholder interaction. The understanding generated will then be important for understanding inter-organizational interaction more generally and CSR strategy and instrumentation more particularly.

\section{Methodology}

\subsection{Infrastructure Inversion}

Theoretically, infrastructure is simple to define: it is the preferred performed forms of communication within a controversy that offer solutions to behavior. Empirically, infrastructure is difficult to unearth and articulate due to its implicit nature. The reconstruction of an infrastructure depends on layers of analysis that foreground some of its observable, visible points (Fredrico, 2010; Star, 1999; Star \& Rutleder, 1995). To draw conclusions about the nature of an infrastructure requires a form of analysis known as infrastructural inversion. Infrastructural inversion is a reflective practice that involves assessing the communication and interaction of actors to ascertain the relevant patterns that impact behavior (Bowker, 1994).

To emphasize the importance of misunderstanding, disagreement, and opposition, communication and interaction is defined here in a pragmatic sense (Aakhus, 2007). Recently there has been a turn to apply design to managerial and professional practices because it explains the construction of forms of communication that are otherwise difficult, impossible, or yet to be imagined. But while pragmatic theories of communication have been predominately used to explain interpersonal and small group interaction, the underlying principles scale to other forms of interaction such as inter-organizational communication (e.g., Aakhus \& Ziek, 2008; Aakhus, 2009).

Pragmatic theories of communication point out that during interaction, any communication can be rejected for it's symbolic (depictions of people, places, texts, Kaufer \& Butler, 1996), actional (performative utterances, Searle, 1975) and mediated (delivery systems, Hutchby, 1984) properties (see Aakhus \& Ziek, 2009; Ziek, 2012). So as far as interaction is concerned, the truly important aspect is how each actor's communication gets taken-up and interpreted by others. Communication does not have to be recognized as when first circulated or publicized and actually, communication does not have to be recognized at all (Jacobs \& Jackson, 1991). The point is that communicative actions spur others to defend themselves, negotiate, argue or ignore the claims, assertions and overtures made. When called-out through expressions of doubt, disagreement, or opposition, a disagreement takes shape and parties to the interaction attempt to repair disruptions to the meaning, actions, or the sense of coherence that had been presumed to be in effect (van Eemeren, Grootendorst, Jackson, \& Jacobs, 1993). The ways that actors manage disagreement is by anticipating, expressing or responding to actual or potential doubt, disagreement, and opposition, which consequently shape the content, direction and outcomes of interaction.

\subsection{Data}

The data for the current inversion was generated from the controversy surrounding Nike's practice of contracting factories with poor working conditions. The current inversion focuses specifically on the peak of the controversy, which was from 1993 to 2004 (Vogel, 2005).The Nike controversy serves as a good case to investigate the role of infrastructure for two reasons. First, it was clearly a time where a corporation was defending its actions and attempting to lift a veil of suspicion or skepticism regarding social expectations. Second, it is also an example where a corporation was able to successfully navigate a controversy usingcommunication. As Doorley and Garcia (2007) explain, "communication has played a key role in every step of Nike's journey through the frequently hostile and always complicated terrain of corporate responsibility" (p. 356). The result of Nike's ability to effectively mitigate the controversy through communicative strategy and instrumentation is that today the company is considered the parent of modern CSR (Epstein-Reeves, 2010) and regular inhabitants on Fortune's list of Most Admired Companies.

Previous research has taken several approaches to studying the communication and interaction relative to the Nike controversy. The first approach describes the entirety of the corporate communication that emerged relative to the situation (e.g., Boje \& Kahn, 2009). The second approach illustrates how particular strategies and instruments were used by Nike such as the code of conduct, lawsuits, cause-related marketing, non-financial report and speeches (e.g., Collins, Zoch \& McDonald, 2004; Ki, 2004; Nijhof, Forterre \& Jeurissen, 2008; 
McHale, Zompetti \& Moffitt, 2007). Finally, numerous studies have dealt with how Nike responded to the pressure from certain stakeholder organizations such as NGOs and the news and entertainment media (Harrison \& Scorse, 2004; Islam \& Deegan, 2008, 2010; Knight \& Greenberg, 2002; Locke, Qin \& Brause, 2007). All of these research trajectories do well to explain the important points about Nike's CSR communication including the emergence of actor roles and the standardization of strategies and instruments, but none of these puts them all together. The Nike controversy was a time where a variety of factors associated with the conditions relative to inter-organizational communication impacted how participating organizations behaved.

When discussing Nike's role in the "sneaker wars", Stabile (2000) argues that little has been done to understand the invisible aspects of socially responsible communication. She further explains that research analyzes what the corporation makes visible in the form of advertising and corporate communication but really research needs to be concerned with making visible the practices and realities that are routinely kept out of site. Infrastructure is precisely this invisible aspect - it is the tacit underlying design for communication that set forth the normative rules of communication so that Nike could successfully navigate the situation.

\subsection{Procedure}

The infrastructural inversion was a three-step process. The first step was to generate a baseline of activity relative to the controversy. Vogel's (2005) account of the Nike controversy and the primary materials he used to create it provided the data on organizational communication and interaction. From there, a range of material and sources was used to fill-out information on the controversy. In all, 27 different references from management, communication and business ethics academic literature were used to flesh out the details of the case such as the primary actors and what communicative strategies and instruments they employed to participate. The second step was to analyze thesymbolic (depictions of people, places, texts, Kaufer \& Butler, 1996), actional (performative utterances, Searle, 1975) and mediated (delivery systems, Hutchby, 1984) properties of each strategy and instrument.Third, the patterns relative to the communication was extracted, i.e. instances of strategy and instrumentation that became standards of communicative behavior for Nike and stakeholder organizations. It is the analysis of these patterns that provided a basis for claims about the nature of the infrastructure for communication and how it was consequential for organizational behavior. By the end of the inversion, what was culled from the raw data was a detailed layout of the strategies and instruments used during the argument-counter argument debate and a way to identify the infrastructure for communication.

Anexample of the procedure can be seen with the action surrounding Transnational Resource and Action Center's (TRAC) 1997 report Smoke from a Hired Gun. The report was a reaction to a labor and environmental audit performed by Ernst \& Young. Smoke from a Hired Gunwas gathered, analyzed and coded for its symbolic, actional and mediated properties. It was coded as criticizing Nike for its decision to hire an organization that had a general lack of understanding regarding how to prepare an independent labor and environmental audit. The specific material called-out by TRAC was the symbolism of the audit, or the way that the audit depicted the landscape of the practice of making footwear and apparel in Nike's contract factories. In this instance, Nike regarded TRAC's actions as an attack that required a defense. Nike's counter-move, which was to hire Good Works International to perform another assessment of life in the plants, was then collected and analyzed for symbolic, actional and mediated properties.

\section{Results}

\subsection{Nike Infrastructure Revealed}

There were five patterns of communication relative to the Nike controversy that point to the emergence of infrastructure. First, although the issues relative to the controversy were based on Nike's operations in Vietnam, Indonesia and China, the majority of participating organizations were based in the United States. Second, even though their roles vary from instigators to collaborators, news and entertainment media and nonprofit organizations were the most active stakeholders. Third, the nature of stakeholder communication was contentious as Nike internalized the particular symbolic qualities as attacks. Fourth, to mediate the adversarial relationships that emerged with stakeholders, Nike stayed away from affective symbolic content. Finally, instruments were predominantly one-way, asynchronous means of communication that limited synchronous feedback such as the non-financial report, code of conduct and mass media. These five patterns of communication were consequential to interaction within the controversy. They occurred often and impacted how the organizations attempted to discipline the controversy through their communication.

Underlying these patterns is the deeper logic of transmission. The transmission logic is where forms of communication are designed to limit interactivity among actors. Incidentally it is also the logic of communication most prevalent in American culture (Carey, 1988). So it is not surprising to see it deeply 
embedded in a controversy largely involving US-based organizations. Identifying the infrastructure through the transmission logic helps to see how these 5 patterns gave order to the emergence of the means of communication However it is also the case that the transmission logic enables us to see what was not afforded by the infrastructure. An infrastructure grounded in the ritual logic of communication would stand in contrast to the infrastructure that developed in the Nike controversy. As Carey (1988) explains, the ritual logic is one where actors share beliefs through participation. An infrastructure that is centered more on participation as opposed to informing would foster a greater understanding of the positions held by both business and society.

As Campbell (2001) explains, "when communication extends beyond managers themselves and also includes other stakeholders, it appears that corporations begin to better appreciate the concerns of these other actors" ( $p$. 933). Although sharing did happen to a degree during the Nike case, the logic more prevalent in the controversy was transmission. So even though the parties did attempt to resist the transmission logic by pushing for forms that enabled something else, the infrastructure still evolved in a way that it supported a one-way communication management system (Ziek, 2008). That is, the ritual logic was not reinforced in the relationships among the organizations instead occurred sporadically throughout the case.

\subsection{Infrastructure at Work}

The infrastructure helped the organizations make sense about how to communicate during the controversy. This was evident in how the organizations, and particularly Nike, developed one-way, asymmetrical communication that gave them control over form and content i.e., code of conduct (Kolk \& van Tuldere, 2002), non-financial report (Locke et al., 2007), print media (Islam \& Deegan, 2008; 2010). Even the widely used inter-organizational alliance, which is supposed to enable dialogue between business and society (Arts, 2002; Zadek, 2005; Zadek \& Radovich, 2006; Ziek, 2011), was carefully designed during the Nike controversy to limit inter-organizational engagements.

More so than any other standardized instrument, the non-financial report is the best example of the role infrastructure played within the controversy. No other instrument best suits the underlying logic of the Nike controversy than the non-financial report. The non-financial report is a one-way instrument that gives the producer an opportunity to control the distribution of quantitative ratings relative to CSR programs and initiatives (Cerin, 2002; Haddock-Fraser \& Fraser, 2008). The non-financial report consists of dozens, even hundreds of pages, of metrics and numerical ratings of social responsibility which mirror the formal structure of financial reporting in the United States (Chatterji \& Levin, 2005; Ziek, 2009).

Nike chose thisinstrument more times than any other as a way to deal with the demand for interaction from its stakeholders. The non-financial report became a way were the corporation could effectively and efficiently satisfy the needs of its stakeholders and do it in a way that mirrored the asymmetrical delivery of Nike's rational, economically-based content. Even though many of the non-financial reports created were products of an alliance between Nike and its stakeholders, the company had ultimate control in whether or not to publish them. In fact, although the report created for Nike by Ernst \& Young was central to the controversy it was never supposed to be released to the public - it was leaked by Nike employees (see Vogel, 2005).

Finally, what reinforces the importance of infrastructure is the fact that the non-financial report was not exclusively used by Nike. TRAC's participation in the controversy was done though the non-financial report. TRAC picked-up the tacit rule suggested by the infrastructure that a legitimate form of communication was the non-financial report. And after the organization used this particular instrument their expression of opposition couldn't go unchecked. The use of the non-financial report during the controversy speaks directly to Carnevale, Mazzuca and Venturini (2012) questions about the relevance of it as a communication tool. The non-financial report is part of an infrastructure for communication that arises to structure the exigencies of interconnected and interdependent organizations. It is just one of the many tools designed by organizations within the allowable bounds of a communication management system.

\subsection{Resource Dependence and Institutional Theory}

Resource Dependence and Institutional Theory run richly through the social sciences. Both emerged as efforts to explain how organizational behavior is shaped by the environment and, in particular, the impact organizations have on each other in an environment (often in unanticipated ways). It is certainly true that communication enables organizations to share resources or adhere to cultural, social and economic institutions. However CSR strategy and instrumentation is not just the conduit through which corporations inform and persuade but something that arises out of the sequences of prior action and anticipated action. As organizations work through the ambiguity of communication to share resources or adhere to institutions what gets generated are patterns and customs of communication that constrain and afford this very communication. 
Resource and institutional perspectives are not dismissed here as the current study is trying to add an element to how these theories explain inter-organizational strategy and instrumentation. As Kallinikos (2006) explains, an infrastructure is built with a backdrop set against the economic and social developments that are taking place within and around an organization. Infrastructure for communication is a consequence of communication; it is an unavoidable expectation of how communication should happen. But in any case, infrastructure for communication is the subtle factor that shapes the way organizations communication for either rational purposes or cultural acceptability.

\section{Limitations}

\subsection{Study Issues}

The current study is not without limitations. First, the data that represents the controversy is small. This limitation is balanced by the context of the study (e.g., Taylor \& Doerfel, 2003). The data certainly shows the back-and-forth move-countermove aspect of CSR controversies (e.g., Aakhus \& Ziek, 2009; Ziek, 2012) where both business and society are attempting to win by building and maintaining both competitive and cooperative relationships. More to the point is that the current study is as much about developing a method to conceptualize the role of infrastructure, as it is about determining an inclusive list of organizations and communicative moves within the Nike controversy - it is truly an exploratory study about how the nature of communication shapes an organization's communicative strategy and instrumentation.

The second limitation has to do with the fact that the current study is based heavily on the qualitative interpretation of one researcher. The description of the organizational moves and interactions which describe the infrastructure were made by one researcher. There is the strong possibility that other researchers might read and interpret the data differently. In other words, questions regarding an "objective of consistency" (Creswell, 2003) can be made. The limitation is balanced by the fact that it is done in a systematic and grounded manner which Wimmer and Dominick (1994) state is necessary for qualitative research. There should be confidence in what is said here because the study gets right to the heart of how the communication context shapes organizational behavior. It does so through an infrastructural inversion that best exemplifies how designs for communication emerge as organizations engage in a chain of reaction relative to a particular circumstance.

\section{Conclusion}

In the burgeoning professional and academic research about CSR there is considerable interest in the communication corporations use to interact with stakeholders. Yet there remains a pervasive misunderstanding of the relationship between CSR communication and the conditions that arise as a corporation interacts with stakeholders. The conventional wisdom emphasizes that communication is about the corporation informing or persuading while missing that communication process takes on a life of its own. So even though CSR communication is often first about marketing and persuasion, it is ultimately co-designed through the give and take between a corporation and its stakeholders.

The group of organizations that came together to debate Nike's social and environmental behaviors was diverse. The key point of commonality, and sometimes the only point, was the controversy. Yet, from the struggle arose patterns of interconnectedness and interdependence among the organizations - an infrastructure -- that provided foundation for the forms of conflict management over CSR. The infrastructure for communication was a solution to how the corporation navigated the context - it provided a tacit mechanism that guided organizational communication. It was not the only solution but it one that emerged to shape the expectations, rules and routines of what is an allowable contribution during interaction.

\section{References}

Aakhus, M. (2007). Communication as design. Communication Monographs, 74(1), 112-117. http://dx.doi.org/10.1080/03637750701196383

Aakhus, M. (2009, August). Transparency work and argumentation design in deliberation about business in society. Paper presented at The 16th NCAAFA Summer Conference on Argumentation, Alta, UT.

Aakhus, M., \& Ziek, P. (2008). Sustainability Communication: A Role for IT and IS in Relating Business and Society. Proceedings of the SIGPrag, Paris, France.

Aakhus, M., \& Ziek, P. (2009). The role of instruments for communicating corporate social responsibility. Paper presented at the National Communication Association, Chicago, IL. 
Alniacik, U., Alniacik, E., \& Genc, N. (2011). How corporate social responsibility information influences stakeholders' intentions. Corporate Social Responsibility and Environmental Management, 18, 234-245. http://dx.doi.org/10.1080/03637750701196383

Argenti, P. A. (2004). Collaborating with Activists: How Starbucks Works With NGOs. California Management Review, 47(1), 91-116.

Arts, B. J. M. (2002). Green Alliances' of Business and NGOs. New Styles of Self-Regulation or 'Dead-End Roads'? Corporate Social Responsibility and Environmental Management, 9, 26-36. http://dx.doi.org/10.1080/03637750701196383

Austin, J. E., \& Cate, R. (2002). Starbucks and Conservation International. Teaching Case 303-055, Harvard Business School, Division of Research, Boston.

Banks, S. P., \& Riley, P. (1993). Structuration Theory as an Ontology for Communication Research. In S. Deetz (Ed.), Communication Yearbook 16 (pp. 167-196). London, Routledge.

Boje, D. (1999). Athletic Apparel Stories and Stock Reports. Retrieved from http://business.nmsu.edu/ dboje/nikestockstories.html (April 11, 2011).

Boje, D. M., \& Kahn, F. R. (2009). Story-branding by Empire Entrepreneurs: Nike, Child Labour, and Pakistan's Soccer Ball Industry. Journal of Small Business and Entrepreneurship, 22(1), 9-24.

Bowker, G. (1994). Information mythology and infrastructure. In L. Bud-Frierman (Ed.), Information acumen: The Understanding and use of knowledge in modern business (pp. 231-247). London: Routledge.

Bra, J., Hanseth, O., Heywood, A., Mohammed, W., \& Shaw, V. (2007). Developing Health Information Systems in Developing Countries: The Flexible Standards Strategy. MIS Quarterly, 31(2), 381-402.

Branco, M. C., \& Rodrigues, L. L. (2006). Corporate Social Responsibility and Resource-Based Perspective. Journal of Business Ethics, 69(2), 111-132. http://dx.doi.org/10.1080/03637750701196383

Campbell, J. L. (2006). Institutional Analysis and the Paradox of Corporate Social Responsibility. American Behavioral Scientist, 49(7), 925-938. http://dx.doi.org/10.1080/03637750701196383

Carey, J. W. (1989). Communication as Culture. Essays On Media and Society. In D. Thornburn (Series Ed.), Media and Popular Culture. A Series of Critical Books. New York: Routledge.

Carnevale, C., Mazzuca, M., \&Venturini, S. (2012). Corporate Social Reporting in European Banks: The Effects of a Firm's Market Value. Corporate Social Responsibility and Environmental Management, 19, 159-144. http://dx.doi.org/10.1080/03637750701196383

Cerin, P. (2002). Communication in Corporate Environmental Reports. Corporate Social Responsibility and Environmental Management, 9, 46-66. http://dx.doi.org/10.1080/03637750701196383

Chatterji, A., \& Levine, D. (2005). Breaking Down the Wall of Codes: Evaluating Non-Financial Performance Measurement. California Management Review, 48(2), 29-51.

Ciborra, C. U. (2007). From control to drift. Oxford University Press: Oxford.

Clark, H. H. (1996). Using Language. Cambridge, UK: Cambridge University Press. http://dx.doi.org/10.1080/03637750701196383

Collins, E. L., Zoch, L. M., \& McDonald, C. S. (2004). When [professional] worlds collide: Implications of Kasky v. Nike for corporate reputation management. Public Relations Review, 30(4), 411-417. http://dx.doi.org/10.1002/csr.144

Collison, D. J., Cobb, G., Power, D. M., \& Stevenson, L. A. (2008). The Financial Performance of the FTSE4Good Indices. Corporate Social Responsibility and Environmental Management, 15, 14-28.

Creswell, J. W. (2003). Research Design.Qualitative, Quantitative, and Mixed Methods Approaches. Thousand Oaks, CA: Sage Publications, Inc.

Cronholm, S., Ågerfalk, P. J., \& Goldkuhl, G. (1999). From usability to actability. In Proceedings of 8th international conference on human-computer interaction (HCI International '99), Munich, August 22-27, 1999.

DeSanctis, G., \& Poole, M. S. (1994). Capturing the complexity in advanced technology use: Adaptive structuration theory. Organization Science, 5, 121-147. http://dx.doi.org/10.1287/orsc.5.2.121 
DiMaggio, P. J., \& Powell, W. W. (1991). Introduction. In W. W. Powell \& P. J. DiMaggio (Eds.), The new institutionalism in organizational analysis (pp. 1-41). Chicago: University of Chicago Press.

Doorley, J., \& Garcia, H. F. (2011). Reputation Management. The Key to Successful Public Relations and Corporate Communication. New York: Routledge.

Epstein-Reeves, J. (2010). The Parents of CSR: Nike and Kathie Lee Gifford. Forbes, June 8. Retrieved from http://blogs.forbes.com/csr/2010/06/08/the-parents-of-csr-nike-and-kathie-lee-gifford/

Frederico, I. (2010). When is an information infrastructure? Investigating the emergence of public sector information infrastructures. European Journal of Information Systems, 19, 35-48. http://dx.doi.org/10.1057/ejis.2010.3

Giddens, A. (1984). The Constitution of Society. Outline of the Theory of Structuration. Cambridge: Polity.

Goffman, E. (1981). Forms of talk. Philadelphia, PA: University of Pennsylvania Press.

Graham, S. (2000). Constructing Premium Network Spaces: Reflections on Infrastructure Networks and Contemporary Urban Development. International Journal of Urban and Regional Research, 24(1), 180-200. http://dx.doi.org/10.1111/1468-2427.00242

Haddock-Fraser, J., \& Fraser, I. (2008). Assessing Corporate Environment Reporting Motivations: Differences Between 'Close-to-Market' and 'Business-to-Business' Companies. Corporate Social Responsibility and Environmental Management, 15, 140-155. http://dx.doi.org/10.1002/csr.147

Hanseth, O., \& Monteiro, E. (1996). Developing information infrastructure: The tension between standardization and flexibility. Science, Technology and Human Values, 21(4), 407-426. http://dx.doi.org/10.1177/016224399602100402

Hutchy, I. (2001). Conversation and technology: from the telephone to the internet. Cambridge, UK: Polity.

Islam, M. A., \& Deegan, C. (2008). Motivations for an OrganisationWithin a Developing Country to Report Social Responsibility Information: Evidence from Bangladesh. Accounting, Auditing and Accountability Journal, 21(6), 850-874. http://dx.doi.org/10.1108/09513570810893272

Islam, M. A., \& Deegan, C. (2010). Media pressures and corporate disclosure of social responsibility performance: A case study of two Global clothing and sports retail companies. Retrieved from http://www.afaanz.org/openconf/2008/modules/request.php?module=oc_proceedings\&action=view.php\&a $=$ Accept + as + Paper\&id $=447$ (May 11, 2009).

Jacobs, S., \& Jackson, S. (1991). Building a Model of Conversational Argumentation. In B. Dervin, L. Grossberg, B. J. O'Keefe \& E. Wartella (Eds.), Rethinking Communication: Paradigm Exemplars (pp. 153-171). Thousand Oaks, CA: Sage Publications, Inc.

Jacobs, S. (1994). Language and interpersonal communication. In M. Knapp \& G. Miller (Eds.), Handbook of interpersonal communication (pp. 199 228). Newbury Park, CA: Sage.

Jawahar, I. M., \& McLaughlin, G. L. (2001). Toward A Descriptive Stakeholder Theory: An Organizational Life Cycle Approach. Journal of Management Review, 26(3), 297-214.

Jones, R. M., Kashlak, R., \& Jones, A. M. (2004). Knowledge flows and economic development through microenterprise collaboration in third-sector communities. New England Journal of Entrepreneurship, 7(1), 39.

Kallinikos, J. (2006). The institution of bureaucracy: administration, pluralism, democracy. Economy and Society, 35(4), 611-627. http://dx.doi.org/10.1080/03085140600960872

Kaufer, D. S., \& Butler, B. S. (1996). Rhetoric and the Arts of Design. Mahwah, NJ: Lawrence Erlbaum Associates, Inc.

Ki, E. (2004). Nike v. Kasky: Reconsideration of noncommercial v. commercial speech. Public Relations Review, 30(4), 419-430. http://dx.doi.org/10.1016/j.pubrev.2004.08.012

Kling, R. (1987). Defining the boundaries of computing across complex organizations. In R. Goland \& R. Hirscheim (Eds.), Critical Issues in Information Systems Research (pp. 307-362). New York: Wiley and Sons.

Kling, R., \& Scacchi, W. (1982). The web of computing: Computer technology as social organization. Advances in Computers, 22, 2-90. 
Knight, G., \& Greenberg, J. (2002). Promotionalism and Subpolitics: Nike and its Labor Critics. Management Communication Quarterly, 15(4), 541-570. http://dx.doi.org/10.1177/0893318902154002

Kolk, A., \& van Tulder, R. (2002). Ethics in international business: multinational approaches to child labor. Journal of World Business, 39(1), 49-60. http://dx.doi.org/10.1016/j.jwb.2003.08.014

Kotler, P., \& Lee, N. (2005).Corporate Social Responsibility. Doing the Most Good for Your Company and Your Cause. Hoboken, NJ: John Wiley \&Sons.

Lammers, J. C. (2003). An Institutional Perspective on Communicating Corporate Responsibility. Management Communication Quarterly, 16(4), 618-624. http://dx.doi.org/10.1177/0893318902250642

Levinson, S. C. (1979). Activity types and language. Linguistics, 17, 365-399. http://dx.doi.org/10.1515/ling.1979.17.5-6.365

Locke, R. M., Qin, F, \&Brause, A. (2007). Does Monitoring Improve Labor Standards? Lessons from Nike. Industrial and Labor Relations Review, 61(1), 3-27.

McHale, J. P., Zompetti, J. P., \& Moffitt, M. A. (2007). A Hegemonic Model of Crisis Communication: Truthfulness and Repercussions for Free Speech in Kasky v. Nike. Journal of Business Communication, 44(4), 374-402. http://dx.doi.org/10.1177/0021943607306137

Nielsen, A. E., \& Thomsen, C. (2011). Sustainable development: the role of network communication. Corporate Social Responsibility and Environmental Management, 18(1), 1-10. http://dx.doi.org/10.1002/csr.221

Nijhof, A., Forterre, D., \&Jeurissen, R. (2008). Managing legitimacy issues in global supply chains: The case of the athletic footwear industry. Corporate Governance, 8(4), 506-517. http://dx.doi.org/10.1108/14720700810899239

Pfeffer, J., \&Salancik, G. R. (1978). The external control of organizations. New York: Harper \& Row.

Porter, M. E., \& Kramer, M. R. (2006). The Link Between Competitive Advantage and Corporate Social Responsibility. Harvard Business Review on Strategy \& Society (pp. 1-14). Boston, MA: Harvard Business School Publishing.

Radin, T. J., \& Calkins, M. (2006). The Struggle Against Sweatshops: Moving Toward Responsible Global Business. Journal of Business Ethics, 66(2-3), 261-272. http://dx.doi.org/10.1007/s10551-005-5597-8

Schultz, F., \& Wehmeier, S. (2010). Institutionalization of corporate social responsibility within corporate communications: Combining institutional, sense making and communication perspectives. Corporate Communications: An International Journal, 15(1), 9 - 29. http://dx.doi.org/10.1108/13563281011016813

Scott, W. R. (2004). Institutional Theory: Contributing to a Theoretical Research Program. In K.G. Smith \& M.A. Hitt (Eds.), Great Minds in Management: The Process of Theory (pp. 460-485). Oxford, UK: Oxford University Press.

Searle, J. R. (1965). What is a Speech Act? In M. Black (Ed.), Philosophy in America (pp. 221-239). Ithaca, N.Y.: Cornell University Press.

Stabile, C. A. (2000). Nike, Social Responsibility, and the Hidden Abode of Production. Critical Studies in Media Communication, 17(2), 186-204. http://dx.doi.org/10.1080/15295030009388389

Star, S. L. (1999). The Ethnography of Infrastructure. American Behavioral Scientist, 43, 377-391. http://dx.doi.org/10.1177/00027649921955326

Star, S. L. (2002). Infrastructure and ethnographic practice: working on the fringes. Scandinavian Journal of Information Systems, 14(2), 107-122.

Star, S. L., \& Ruhleder, K. (1996). Steps toward an ecology of infrastructure: Designing and access for large information spaces. Information Systems Research, 7(1), 11-134. http://dx.doi.org/10.1287/isre.7.1.111

Taylor, M., \& Doerfel, M. L. (2003). Building inter-organizational relationships that build nations. Human Communication Research, 29(2), 153-181. http://dx.doi.org/10.1111/j.1468-2958.2003.tb00835.x

Transnational Action Resource Center. (1997). Smoke from a Hired Gun. Retrieved from http://www.corpwatch.org/article.php?id=966 (January 12, 2009).

Turban, D. B., \& Greening, D. W. (1997). Corporate social performance and organizational attractiveness to prospective employees. Academy of Management Journal, 40, 658-672. http://dx.doi.org/10.2307/257057 
vanEemeren, F. H., Grootendorst, R., Jackson, S., \& Jacobs, S. (1993). The pragmatic organization of conversational argument. Reconstructing Argumentative Discourse (pp. 91-116). Tuscaloosa, AL: University of Alabama Press.

Vogel, D. (2005). The Market for Virtue. The Potential and Limits of Corporate Social Responsibility. Washington, DC: The Brookings Institute.

Wimmer, R., \& Domminick, J. (1994). Mass Media Research (4th ed.). Belmont: Wadsworth.

Zadek, S. (2005). The Logic of Collaborative Governance Corporate Responsibility, Accountability, and the Social Contract. Corporate Social Responsibility Initiative, Kennedy School of Government, Working Paper \# 2.

Zadek, S., \& Radovich, S. (2006). Governing Collaborative Governance: Enhancing Developing Outcomes by Improving Partnership Governance and Accountability. working paper, Kennedy School of Government.

Ziek, P. (2008). An Examination of Mediated Dialog between Business and Society. In K. O’Sullivan (Ed.), Proceedings of the $5^{\text {th }}$ International Conference on Intellectual Capital, Knowledge and Organisational Learning (pp. 549-555). New York Institute of Technology, New York, NY: New York Institute of Technology.

Ziek, P. (2009). Making Sense of CSR Communication. Corporate Social Responsibility and Environmental Management, 16(3), 137-145. http://dx.doi.org/10.1002/csr.183

Ziek, P. (2011a). The Role of Interorganizational Alliances in Environmental Sustainability. The International Journal of Environmental, Cultural, Economic and Social Sustainability, 7(1), 103-116.

Ziek, P. (2012). Infrastructure as the blueprint for CSR communication strategy and instrumentation. In T. Golden (Ed.), Proceedings of the Eastern Academy of Management 2012 Annual Meeting (pp. 1031-1054). Philadelphia, PA: LaSalle University. 